Cahiers $d u$ MONDE RUSSE

\section{Cahiers du monde russe}

Russie - Empire russe - Union soviétique et États indépendants

$46 / 1-2 \mid 2005$

La Russie vers 1550

\title{
A few notes about the strigol'niki heresy
}

\section{Alexey I. ALEXEEV}

\section{OpenEdition \\ Journals}

Édition électronique

URL : https://journals.openedition.org/monderusse/8805

DOI : $10.4000 /$ monderusse. 8805

ISSN : $1777-5388$

Éditeur

Éditions de l'EHESS

Édition imprimée

Date de publication : 1 janvier 2005

Pagination : 285-296

ISBN : 2-7132-2055-6

ISSN : $1252-6576$

Référence électronique

Alexey I. ALEXEEV, «A few notes about the strigol'niki heresy », Cahiers du monde russe [En ligne], 46/1-2 | 2005, mis en ligne le 01 janvier 2007, consulté le 02 septembre 2022. URL : http://

journals.openedition.org/monderusse/8805; DOI : https://doi.org/10.4000/monderusse.8805

Tous droits réservés 
chercher : repérer : avancer

Cet article est disponible en ligne à l'adresse :

http://www.cairn.info/article.php?ID REVUE=CMR\&ID NUMPUBLIE=CMR 461\&ID ARTICLE=CMR 4610285

\title{
A few notes about the strigol' niki heresy
}

\author{
par Alexey I. ALEXEEV
}

\section{Editions de l'EHESS | Cahiers du monde russe}

\author{
2005/1-2 - Vol 46 \\ ISSN 1252-6576 | ISBN 2713220556 | pages 285 à 296
} conditions générales d'utilisation du site ou, le cas échéant, des conditions générales de la licence souscrite par votre établissement. Toute autre reproduction ou représentation, en tout ou partie, sous quelque forme et de quelque manière que ce soit, est interdite sauf accord préalable et écrit de l'éditeur, en dehors des cas prévus par la législation en vigueur en France. Il est précisé que son stockage dans une base de données est également interdit. 


\section{A FEW NOTES ABOUT THE STRIGOL 'NIKI HERESY}

1.

The first data on the movement hostile to the Church, which has received the settled name strigol'niki in accusatory epistles of the Church hierarchs, are found in the Epistle to Pskov by Patriarch Nil (1382). ${ }^{1}$ The longest text serving as a source on the history of the strigol'niki - the Homily by bishop Stephan of Perm - dates back to $1386 .{ }^{2}$ The execution of strigol'niki in Novgorod was mentioned in the First Chronicle of Saint Sophia (hereafter: S I; first half of the fifteenth century ${ }^{3}$ ) and in the Fourth Novgorod Chronicle (hereafter: N IV) under the 1375/76 entry. ${ }^{4}$ As Ia. S. Lur'e has shown, the Fourth Novgorod Chronicle is dependent on S I for the information on the execution of strigol'niki, and this information could perhaps be traced back to the lost Codex of 1418..$^{5}$ Executions of leaders of the movement had no obvious signs of sanctions from the side of church or secular authorities and apparently did not put an end to the movement as a whole.

Existing sources give no more information on the strigol'niki in Novgorod, but this fact mainly illustrates the specifics of relations between the Moscow metropolitan and Novgorod's archbishop. It reveals nothing about the success of

1. N. A. Kazakova, Ia. S. Lur'e, Antifeodal'nye ereticheskie dvizheniia na Rusi XIV - nachala XVI vv. [Anti-feudal Heretic Movements in 15th - beginning of 16th Century], (M.-L., 1955), Appendices: 234 (hereafter: $A F E D$ ).

2. AFED: 236-241.

3. PSRL, vol. 6 (M., 2000), B. 1, col. 449.

4. PSRL, vol. 4/1 (M., 2000): 305. The execution is also mentioned in the Novgorod Chronicle under the year 6884 , in the manuscript of P.P. Dubrovskii, which was, according to O. L. Novikova, the codex presented to the archbishopric of Novgorod in the 1540's. PSRL, vol. XLIII (M., 2004): 126.

5. Ia. S. Lur'e, Obshcherusskie letopisi $X I V-X V$ vV. [Pan-Russian Chronicles from the 14th15th Centuries] (L., 1976): 73-78; Ja. S. Lurie, "Review of the book by B. A. Rybakov, Strigol'niki,” Russia Mediævalis, vol. VIII, 1 (Munich, 1995): 143-144. 
the Church in repressing the heresy. ${ }^{6}$ From the Epistles of Metropolitan Photius to Pskov (1416-1429) it is obvious that the strigol'niki were still disturbing public opinion in Pskov in the first quarter of the fifteenth century. ${ }^{7}$ In 1490 Novgorod Archbishop Gennady in his epistle to the high clergy council exposed monk Zachary as being in affiliation with the strigol'niki. ${ }^{8}$ In the beginning of the sixteenth century Joseph of Volotsk wrote in the $16^{\text {th }}$ article of his Prosvetitel about an originator of the strigol'niki heresy named Karp. ${ }^{9}$

\section{2.}

In high clergymen's accusatory epistles the strigol'niki heresy had the traits of a sect with a developed heretical doctrine performed as a complete system. The strigol'niki repudiated the church hierarchy corrupted by simony; they did not believe in the power of the holy sacraments when administered by unworthy priests; among other things, they rejected individual confession and the necessity of funeral services. Solving of the problem of the time of origin of the strigol'niki is closely connected with the researchers' ideas on the very nature of this movement. The overwhelming majority of scholarly paradigms are based on the prerequisite of the rationalistic character of the heresy. Let's quote for instance from M. Liubavskii:

The strigol'niki heresy was the brightest manifestation of the rationalistic trends in the spiritual life of the Russian community, which was generally enslaved by church tradition and mysticism. ${ }^{10}$

The most popular approach among historians is based on the conception of a developed municipal organization of Novgorod and Pskov and of a far-gone social

6. A hypothesis on Metropolitan Kiprian's active role in the massacre of the strigol'niki was presented for the first time in I. I. Malyshevskii, "O zarozhdenii religioznykh sekt v Rossii s ratsionalisticheskim napravleniem" ["On the Arising of Rationalistically Oriented Religious Sects in Russia”], Trudy Kievskoi Dukhovnoi Akademii, 12 (1883): 671-676. An attempt has recently been made to prove this hypothesis: M. V. Pechnikov, "Spornye voprosy istorii strigol'nichestva v Novgorode vo vtoroi polovine XIV v.," in Goroda Rusi i Rossii v srednie veka i v rannee novoe vremia, XI-XVIII vv. Doklady Tret'ei nauchnoi konferentsii ["Controversial Questions about the Strigol'nik Movement in Novgorod during the Second Half of Fifteenth Century," in Towns of Rus' and Russia during the Middle Ages and Early Modern Period, 11th-18th Centuries). Papers Presented at the Third Conference] (Murom, May 17-20,2000),(M., 2003): 147-149.

7. See: "Poslaniia mitropolita Fotiia v Pskov 1416-1427" ["Epistles of Metropolitan Photius to Pskov, 1416-1427'], AFED: 243-255.

8. AFED: $378,380$.

9. Prosvetitel' [The Illuminator], (Kazan, 1904): 541-542.

10. M. Liubavskii, Drevniaia russkaia istoriia do kontsa XVI v. [History of Ancient Russia to the End of Sixteenth Century], (M., 1918): 210; N. A. Kazakova, "Novgorodsko-pskovskaia eres' strigol'nikov XIV-XV vv." ["The Novgorod-Pskov Heresy of Strigol'niki, 14th-15th Centuries"], AFED: 47 sq. 
differentiation of town people in these cities. They took for granted that the specifics of the church institutions of the Veche republics played a decisive role in the origin of the strigol'niki heresy. Reading sources too literally, researchers supposed payment for ordainment was the starting point for the heresy. ${ }^{11}$ According to the Marxist postulate that heresies were a form of class struggle of city plebes against the ideology of the ruling church, researchers tried to build a connection between the origin of the strigol'niki heresy and the numerous popular disturbances in Novgorod. ${ }^{12}$ Because known sources cannot justify such a construction, this model for the genesis of the strigol'niki heresy is doomed to remain an ideological concept and nothing more. The only faint resemblance researchers were able to find was in the Narrative on Moses written by Pahomy the Serb about 1470; he declared that a Novgorod archbishop (1352-1359) "blamed the heresy of the evil-plotting strigol'niki."13

If the strigol'niki heresy was not a specific form of class struggle, could we say that the fact that it first appeared in Novgorod and Pskov - the cities of Russia unexampled in openness for interrelations with countries of Western Europe was a matter of chance? The affirmative answer to this question gives us the second scholarly paradigm of research on the strigol'niki heresy. It is framed on the hypothesis of outer ideological influences either from countries of the Latin West or from the countries of the Byzantine oecumen. N. S. Tikhonravov and A. N. Veselovskii pointed at the ecstatic religious movement of flagellants initiated with the devastating "Black Death" pandemic as a possible source of the strigol'niki heresy. ${ }^{14}$ Nowadays, the idea of the ideological influence of the Bogomil movement is still topical. ${ }^{15}$ It was argued mainly by F. I. Uspenskii, who supposed that the dualistic features of the metaphysical attitudes of the strigol'niki put them on the same level with the Bogomils. In that case, as a matter of principle, the ways and means of transference of the Bogomil doctrine to Novgorod and Pskov should have been explored. The question remains open to this day. ${ }^{16}$ In recent years, in the discussion on the role of Paulician and Bogomil influences on West-European

11. A. I. Nikitskii, Ocherk vnutrennei istorii Tserkvi $v$ Velikom Novgorode [Essay on the Internal History of Church in Novgorod], (SPb., 1879): 146.

12. L. V. Cherepnin, Obrazovanie Russkogo tsentralizovannogo gosudarstva $v X I-X V$ VV. [The Formation of the Centralized Russian State, 11th-15th centuries], (M., 1960): 683.

13. Pamiatniki starinnoi russkoi literatury, vol. IV: 11. M. V. Pechnikov. "Spornye voprosy...”, art . cit.: 138-139. See: B. A. Rybakov, Strigol'niki (M., 1993): 11, 271-291.

14. N. S. Tikhonravov, Sochineniia [Works], vol. 1 (M., 1898): 215; A. N. Veselovskii, "Opyty po istorii razvitiia khrist ianskoi legendy" ["Essays on the Development of a Christian Legend"], ZhMNP,(1876, March): 116.

15. K. F. Radchenko, Religioznoe i kul'turnoe dvizhenie v Bolgarii v epokhu pered turetskim zavoevaniem [Religious and Cultural Movement in Bulgaria at the Eve of Turkish Invasion], (Kiev, 1898); E. Hösch, Orthodoxie und Häresie im alten Russland (Wiesbaden, 1975).

16. F. I. Uspenskii, Ocherki po istorii vizantiiskoi obrazovannosti [Essays on the History of Byzantine Education], (M., 2001): 308 (1 ${ }^{\text {st }}$ edition 1891). Modern researchers refuse the possibility of a transference of Bogomil literature to Russia (J.-P. Arrignon, "La Rus' entre la Bulgarie et l'Empire byzantin de la fin du $\mathrm{X}^{\mathrm{e}}$ au début du XII e siècle," Proceedings of the International Congress Commemorating the Millenium of Christianity in Rus' - Ukraine (N.Y., 1988/1989): 702-713). 
heresies, common opinion has adopted a more moderate position. ${ }^{17}$ The decisive argument is the perception of the fact that the Bogomil movement was mainly a peasant movement without such an ideological potential as could be exported. Traces of the dualistic dogma typical of the Bogomils and Cathars can be detected in the accusatory literature aimed against the Manicheans. There are no evident traces of the Bogomil doctrine in the sources on the strigol'niki. The rapprochement of Bogomil and strigol'niki doctrines has no documentary support. ${ }^{18}$ Thus, it is impossible to give decisive importance to the factor of ideological influences in the origin of the heresy.

A separate research paradigm is an attempt to analyze the strigol'niki heresy as a pagan emotional experience that goes as far as denying the Christian nature of the sect. ${ }^{19}$ The brightest example of such an approach is found in the works of V. V. Mil'kov, who considers that "the strigol'niki heresy restored a non-Christian cult complex and non-Christian ideas." 20

Admittedly, many religious phenomena between the eleventh and the fifteenth centuries and even later present striking particularities; but should we really explain this fact by the tenacity of pagan remnants? Here, we obviously come up against the limits of the dual belief model that was rather popular and long-lived in Soviet historiography. ${ }^{21}$

B. A. Rybakov occupies a special place in the historiography of the strigol'niki heresy; he characterized it as a humanistic doctrine, adherents of which "took care of observing the Christian Orthodox rite with the clean hands of pure people". ${ }^{22} \mathrm{An}$

17. See H.-G. Beck, Vom Umgang mit Ketzern. Der Glaube der kleinen Leute und die Macht der Theologen (Munich, 1993): 81-82; D. I. Polyviannyi, Kul'turnoe svoeobrazie srednevekovoi Bolgarii $v$ kontekste vizantiisko-slavianskoi obshchnosti $I X-X V \quad V v$. [Originality of Bulgarian Culture in the Byzantine-Slavic Ecumen Context, 9th-15th Centuries], (Ivanovo, 2000): 90-93. The opposite point of view: E. Werner, M. Erbstösser, Kleriker, Mönche, Ketzer. Das religiöse Leben im Hochmittelalter (Berlin, 1992): 82. For a detailed review of the literature on the Bogomils: K. Gencheva, Bogomilstvoto. Bibliografiia (Sofia, 1997). See also: Pravoslavnaia êntsiklopediia [Orthodox Encyclopædia], vol. V (M., 2002): 471-473.

18. It is interesting that researchers tried to arrogate Bogomil positions to Avraamii of Smolensk because he read glubinnye knigi ["esoteric, apocryphal writings"] according to the words of his hagiographer. See: G. P. Fedotov, "'Life' and 'Passion' of st. Avraamy of Smolensk," Izbrannye stat i, vol. II (M., 1999): 169-189.

19. See: A. S. Orlov, Drevniaia russkaia literatura [Literature of ancient Russia], (M.-L., 1945): 239-240.

20. See: "Strigol'niki," Ideinye techeniia drevnerusskoi mysli [Trends in the History of Thought in Ancient Russia], (SPb., 2001): 311. See also: V. V. Mil`kov, Mirovozzrencheskie problemy rannesrednevekovykh eresei na Rusi, XI-XIV Vv. [Problems of Weltanschauung in Early-Medieval Heresies in Russia, 11th-14th Centuries], (M., 1981); "Uchenie strigol'nikov," Obshchestvennaia mysl': Issledovaniia i publikatsii ["The strigol'niki doctrine," History of Ideas : Research and Publications], (M., 1993), B. IV: 33-46.

21. V.M. Zhivov notes: "Synchronically in any Christian culture pagan inheritance is fragmented, and each of these fragments can be defined as a pagan one only in a genetic way, in a diachronic perspective.” V. M. Zhivov, Razyskaniia v oblasti istorii i predistorii russkoi kul'tury [Research in History and Proto-history of Russian Culture], (Moscow, 2002): 309.

22. B. A. Rybakov, Strigol'niki, op. cit.: 333. 
essential weakness of Rybakov's arguments was his attempt to voluntarily broaden the circle of sources on the strigol'niki heresy to monuments of erudition (the Trifonovskii collection, Izmaragd, the Frolov Psalter, etc.) or archeology (veneration crosses [poklonnye kresty], church frescoes). A similar position is now held by M. V. Pechnikov. He presents in strigol'niki who advocated pure belief not as heretics, but rather dissenters. ${ }^{23}$

The groundlessness of all the above mentioned attempts to establish a connection between the strigol'niki and a certain social group and to provide the movement with a time frame has led us to the idea that the basic premise is false. Accusatory epistles by hierarchs did not aim to give a correct and full description of the heresy. And it would be erroneous to hypothesize that the accused strigol'niki were organized like a sect. It is known that medieval theologians used catalogues of heresies composed in the times of the late Patrology for the accusation of current and actual heresies. That is why accusations against the Manicheans were readdressed to the Paulicians and then to the Bogomils and so on. According to the practice of Byzantium, all new heresies were related to Judaism, Barbarism, Scythian or Hellenistic beliefs. But we should explain why both Bishop Stephan and Metropolitan Photius preferred to call heretics strigol'niki.

\section{3.}

There is a dominant version according to which the name of the heresy derived from the verb "to cut" (strich', strigat'). The name strigal (cutter) was used for craftsmen producing woolen cloth; some of them were involved in the heresy. ${ }^{24}$ Such an etymology is perfectly suited to the idea of heresy as a form of class struggle in the medieval period. In later historiography this opinion received broad

23. See: M. Pechnikov, "Doktrina strigol'nikov: opyt rekonstruktsii" ["The Strigol'niki Doctrine: A Tentative Reconstruction”], Russia Mediævalis, vol. X, 1 (Munich, 2001): 107 125 ; idem, "K voprosu o vremeni i obstoiatel'stvakh vozniknoveniia novgorodsko-pskovskoi sekty strigol'nikov," in Stolichnye i periferiinye goroda Rusi i Rossii v srednie veka i v rannee novoe vremia (XI-XVIII vv.) Doklady Vtoroi nauchnoi konferentsii, Moskva, Dekabr' 7-8, 1999) ["On the Problem of When and in What Circumstances did the Novgorod-Pskov Sect of Strigol'niki Appear," in Capital and Provincial Cities of Rus' and Russia during the Middle Ages and Early Modern Period (11th-18th Centuries). Papers Presented at the Second Conference (Moscow, December 7-8, 1999)] (M., 2001): 278-287; M. Pechnikov, "Spornye voprosy...", op. cit: 137-151. In the canonic tradition of the Orthodox Church there was a difference between heresy and schism. Heretics were supposed to be those who completely separated from the Church and lost faith; schismatics were supposed to be those who had different thinking on several church subjects and questions that could be more or less easily conciliated. See: Pravila Pravoslavnoi tserkvi s tolkovaniiami Nikodima, episkopa Dalmatinsko-Istrinskogo [Orthodox Church Rules, with Comment by Nicodemus, Bishop of Dalmatia-Istria], vol. II (SPb., 2001) (reprint 1911): 369-370. G. P. Fedotov held the position that the strigol'niki should be considered not as heretics but as schismatics (dissenters). G. P. Fedotov, The Russian Religious Mind, vol. 2 (Cambridge, 1966): 116.

24. N. M. Nikolskii, Istoriia russkoi tserkvi [History of Russian Church], (M., 1930): 71-75. 
support ${ }^{25}$ and was proved right with Russian sources of the second half of the sixteenth century and of the seventeenth century. ${ }^{26}$ There is also a hypothesis explaining the name of the heresy by the rite of taking the monastic vow. ${ }^{27}$ The use of the term strigal to designate craftsmen was registered in sources dating from 150 years after the heresy. Linguistic arguments are not enough to base the explanation of the name of the heretics strigol'niki on the verb strich' '.28 This etymology does not allow us to explain why the church hierarchs' designation of heretics as strigol'niki stayed on, and why the latter were highly popular among common people. ${ }^{29}$ It seems unlikely that church hierarchs should have used a term from the vernacular to define a heresy. There existed the nickname Striga in fifteenthcentury Russia (Prince Ivan Vasil'evich Striga-Obolenskii); by the city of Ustiug there was the river Striga; among the few attested pagan gods there was Stribog the god of evil. ${ }^{30}$

Roman Jakobson supposed that etymologically the noun strigol'niki could be traced back to an ill-omened personage of black magic. ${ }^{31}$ It is known that in Byzantine and Roman mythology the term "striga" was used for designating sorcerers and vampires-werewolves. ${ }^{32}$ Records of "striga" were found in the church's accusatory literature, ${ }^{33}$ documents on witch trials and in anti-heretic treatises. As Carlo Ginzburg has shown, the concept of "striga" as a central personage injuring men and cereals was the opposite of such characters as the "benandanti," who belonged to a fertility cult. ${ }^{34}$ Belief in "striga" was registered in

25. B. W. Kiessler, Die Häresie der Strigol'niki (Saarbrücken, 1969): 29-42; E. Hösch, Orthodoxie, op. cit.: 63-68.

26. Pistsovye knigi Kazani 1565-1568 i 1646 g. [Cadastral Surveys of Kazan’ District, 1565 1568 and 1646], (M., 1932): 18.

27. N. A. Kazakova, "Novgorodsko-pskovskaia eres'...," art. cit:57-58.

28. M. Vasmer, Etimologicheskii slovar' russkogo iazyka [Etymological Dictionary of the Russian Language], vol. III (SPb., 1996): 778 (Russian translation of: idem, Russisches etymologisches Wörterbuch (Heidelberg, 1950-1958), q. v.)

29. See: A. V. Poppe, "Eshche raz o nazvanii novgorodsko-pskovskikh eretikov strigol'nikami," Kul'tura Drevnei Rusi ["Once again about the naming of Novgorod-Pskov heretics - strigol'niki," Culture of Ancient Russia], (M., 1966): 207.

30. D. K. Zelenin, "Êtimologicheskie zametki" ["Etymological Remarks"], Izvestiia otdeleniia russkogo iazyka i slovesnosti, vol. IV (1903): 268; for the list of literature with notes of main points of view concerning "Stribog," see: Êntsiklopediia Slova o polku Igoreve [Encyclopædia of the Tale of the campagn of Igor'], vol. 5 (SPb., 1995): 68-70.

31. R. Jakobson, "Marginalia to Vasmer's Etymological Dictionary (R - Ja)," IJSLR, Bd. 1/11 (1959): 272.

32. I. Sorlin, "Striges et géloudes. Histoire d'une tradition," Travaux et Mémoires de l'Institut d'Études byzantines, (Paris), t. 11 (1991): 413.

33. John Damascene, Opera, ed. P. M. Lequien, vol. I (1864): 473.

34. C. Ginzburg, Die Benandanti: Feldkulte und Hexenwesen im 16. und 17. Jahrhundert (Hamburg, 1993): 216. 
numerous sources of the East-Slavic area. ${ }^{35}$ This etymological variant was long considered preferable because it made it possible to explain the strigol'niki's high authority over the people and the manner in which they were executed..$^{36}$ The weak point of this hypothesis is the absence of traces of the origin of this etymology in the Russian canonical tradition.

More proven seems the etymology of the word strigol'niki that is traced back to the texts of the Kormchaia kniga (Nomokanon, or Book of canonic rules), because only through this channel could the word come into the hierarchs' epistles. The $21^{\text {st }}$ rule of the Sixth Ecumenical Council provides such a norm that repentant unfrocked priests receive the right to be tonsured like clergymen. In the opposite case, they must grow their hair like all the other laymen. ${ }^{37}$ Unfrocked priests could receive the right to keep the appearance of clergymen but in other aspects they were equated with laymen. In the so called Speech of the Judaic Language, included in the Novgorod version of Kormchaia kniga, we can find a dictionary entry: "britva [razor] - strigolnik. ${ }^{38}$ Shown arguments, in our opinion, explain satisfactorily the etymology of the name of the heresy.

In the early information from the chronicles on the execution of strigol'niki (S I and N IV), as well as in the Homily of Stefan of Perm, the term strigol'nik was constantly used in connection with the deacon position of Mikita and Karp. As for

35. See: L. N. Vinogradova, Narodnaia demonologiia i mifo-ritualnaia traditsiia slavian [Popular Demonology and Mythic-Ritual Tradition among the Slavs], (M., 2000): 14, 22, 103, 230-231, 237, 243, 301; M. Vlasova, Russkie sueveriia. Êntsiklopedicheskii slovar' [Russian Superstitions. An Encyclopedic Dictionary], (SPb., 1998): 491.

36. See: A. I. Alekseev, "Eres' strigol'nikov: vol'nodumtsy ili kolduny?," Issledovaniia po russkoi istorii. K 65-letiiu prof. I. Ia. Froianova ["Where the Strigol'niki Free-Thinkers or Wizards?," Research on Russian History. To Professor I. Ia. Froianov for his 65th Birthday], (SPb., 2001): 184-195.

37. Let us quote from the Riazanskaia Kormchaia kniga [Riazan’ Nomokanon] of 1284 (6792), Rossiiskaia natsional'naia biblioteka, Saint Petersburg (RNB [Russian National Library]), Parchment fund, $n^{\circ}$ II, f. 147 verso-148. Sixth Ecumenical Council, Rule 21: "Izhe otniud' izverzhen $v$ prostye liudi otrinoven pokaiavsia, da strizhet'sia tokmo, ashche li ni vlasy rastit. Tolk: Prozviter ili diiakon, ashche budet ot sana izverzhen, chest' zhe da imat' i sedalishche, jako zhe i prochim sushchim v prichte glavu da postrigaiut, rekshe na glave sushchee gumn'tse, ashche zhe grekhovnyia radi viny budet izverzhen otniud' i s prostymi liud'mi na meste postavlen. Ashche ubo svoeiu voleiu ostavit grekh, ego zhe radi blagodati Bozhia lishisia i chesti i ashche na obrashchenie zrit, iako zhe prichetnitsi, glavu da postrigaet. Ashche zhe i svoeiu voleiu ne otstupit', no tvoriti hoshchet grekh, iakozhe i mir'stii chelovetsi, vlasy da rastit', iakozhe vozliubiv mir'skoe prebyvanie pache nebesnyia zhizni."

See also: Pravila Pravoslavnoi tserkvi (op. cit., note 23), vol. I: 494-495. The tradition to shave hair on the top of the head (gumentso or papalitra) has been established in Western and Eastern Christianity approximately since the sixth century. In Byzantium it existed at least till the end of the fifteenth century; and in Russia it was in practice up to the beginning of the eighteenth century (ibid.: 497). This rule was included in all the variants of the Kormchaia kniga known in Russia. See: I. I. Sreznevskii, Obozrenie drevnikh russkikh spiskov kormchei knigi [A Survey of Old-Russian Manuscripts of the Nomokanon], (SPb., 1897): 142.

38. L. S. Kovtun, Russkaia leksikografiia êpokhi srednevekoviia [Lexicography in Russia in the Middle Ages], (M. - L., 1963): 400, § 12. Orthographic variants: ostrigol'nik (Gosudarstvennyi istoricheskii muzei - GIM [State Historical Museum, Moscow], ms. Syn. 132); strigolnik (Rossiiskaia gosudarstvennia biblioteka - RGB [Russian State Library], ms. Rum. 231); strigalnik (RNB, ms. Pogod. 1309). 
the testimony by Joseph of Volotsk, we take the opinion that he applied the term khudozhestvo ("art") for strigol'niki not to mention a craft but a negative, pejorative characteristic. Thus, the most sensible version of the name of the heresy is as follows: it is traced back to the naming of defrocked clergymen who took the role of teachers denied them by the canonic rule..$^{39}$ This version also tallies with the information on the literacy and education of the strigol'niki, which could be easily explained through their affiliation with the clergy.

\section{4.}

Is it possible to show the typological parallels to the strigol'niki heresy in the history of West-European heresies? We think so. The mass heretic movements of Europe originated in mounting opposition to a simony interpreted as buying spiritual titles for money. The main motives of the Patarini in Milan, Piacenza and Cremona in the second half of the eleventh century were their doubts about priests' ability to bestow grace. Headed by defrocked clergymen, they accused the archbishop of Milan and his clergy of simony and Nicholaism (interpreted as a breach of the vow of celibacy). They called the host in the hands of impious priests "food for dogs"; they threw it to the ground and trampled it. Radical laymen fought for the right of the town community to choose their priests and archbishop. The duplicity of the position of Rome was due to its desire to bring the mighty archbishop of Milan under control as well as with the will to protect the clergy from laymen's accusations. An agreement between the papal administration and moderate Patarini was reached in the years of the pontificate of Gregory VII. The momentum of the Patarini movement was used by the Pope in the framework of the Church's reforms program which included fighting against secular authorities for the right of investiture and establishing strict control over the clergy. ${ }^{40}$

In Russia, levying payment for ordainment was officially established by a decision of the Vladimir Council in 1274. The rule of Metropolitan Cyril regulated the amount to be paid. ${ }^{41}$ It is especially interesting that this rule was included in several Kormchie knigi of the fourteenth century and was ignored in the Kormchie knigi of the fifteenth century. Judging from the table of contents, it was included in the canonic compilation Vlasfimiia [Blasphemy] - a very important work for the present article - but is missing from the only two known copies of Vlasfimiia. ${ }^{42}$

39. See: "Poslanie mitropolita Fotiia v Pskov" [Epistle of Metropolitan Photius to Pskov], AFED: 250.

40. E. Werner, M. Erbstösser, op . cit. (note 17): 89-95. Why these heretics were called Patarini is still enigmatic. Even contemporaries of the heresy tried to explain this etymology, in vain. For a period of time, it was thought that the name could be traced back to such words as "weaver" or "junk-dealer." But nowadays this etymology seems a vexed question (ibid.: 87-89).

41. RIB, vol. VI (SPb., 1908), col. 86-93.

42. RNB, ms. Soph. coll. $n^{\circ} 1262$, f. 63 verso-113 (beginning of the fifteenth century); ms. Solov. coll. $\mathrm{n}^{\circ}$ 1085/1195, f. 628-684 (1504). 
The overwhelming majority of the articles in Vlasfimiia constitute a collection of canonic rules and patrological texts indicting simony. Discussions on the "recompense for ordainment," which began in Russia in the fourteenth century, ${ }^{43}$ were still going on in the fifteenth and sixteenth centuries. The question of the permissibility of paying in order to be ordained was discussed at the Councils of 1503 and 1551.44 "Recompense for ordainment" as a bad custom in Novgorod and Pskov was mentioned in the $14^{\text {th }}$ and $15^{\text {th }}$ questions of the $40^{\text {th }}$ chapter of Stoglav ${ }^{45}$ Obviously, in the fourteenth century, the custom of payment for ordainment became a problem of primordial importance and the main cause for disagreement between the strigol'niki and the Church. In spite of all the differences between the urban communes of Milan and Novgorod, we are inclined to see a typological similarity between the movement of the Patarini of the eleventh century and the heresy of the strigol'niki at the turn of the fifteenth century.

\section{5.}

The Catholic Church's hierarchy not only persecuted heretics but also took various actions to raise the level of education and authority of priests. In the fourteenth and fifteenth centuries a similar situation took place in Russia. In the Mazurinskii variant of the Kormchaia (end of the fifteenth century), five articles of Part 8 are devoted to accusations against bishops and presbyters, who "do not teach people." 46 Numerous articles of edifying anthologies of the fourteenth and fifteenth centuries were devoted to accusations of ignorance and impiety against the clergy. The following is a short list of examples from the Trifonovskii collection of the turn of the fifteenth century. In the article Pred'slovie chestnago pokaianiia (Preface to an honest repentance), we can read:

43. On the Pereiaslavskii council of 1311 (6820) see: Pl. Sokolov, Russkii arkhierei iz Vizantii [A Russian Prelate from Byzantium], (Kiev, 1913): 218-260. For publications of documents see: "Poslanie patriarkha Nifonta velikomu kniaziu Mikhailu" ["Epistle of [Constantinople] Patriarch Niphon to Grand Prince Mikhail "], (RIB, vol. VI., col. 147-149) and "Napisanie Ankindina mnikha k velikomu kniaziu Mikhailu ["Epistle of Monk Akindin to Grand Prince Mikhail"'], (ibid., col. 150-158).

44. AAE, vol. I, n 382; E. B. Emchenko, Stoglav. Issledovanie i tekst [The Stoglav. Study and text], (M., 2000): 305. See English translation: J. E. Kollmann, The Moscow Stoglav (Hundred Chapters) Church Council of 1551 (Ann Arbor, 1982) or French translation: É. Duchesne, Le Stoglav ou les Cent chapitres (Paris, 1920).

45. See: E. B. Emchenko, Stoglav, op. cit.: 309. This text leads us to refuse the idea that abuses in ordainments could be perpetrated by high clergymen alone. See: “A tol'ko vladyka popa prishlet $\mathrm{k}$ toi tserkvi, khotia gramote gorazd i chiuvstven, a tolko mnogikh deneg ulichanom ne dast i oni ego ne primut" ["When the archbishop sends a priest to be vicar of a church, even if he is learned and sensible, if he doesn't give enough money to the street-dwellers, he will not be accepted"].

46. Mazurinskaia kormchaia. Pamiatnik mezhslavianskikh kul'turnykh sviazei XIV-XVI VV. Issledovanie. Teksty [The Mazurinskii Nomokanon. A Monument of Interslavic Cultural Relations of the 14th-16th Centuries. Studies. Texts], prepared by E. V. Beliakova, K. Ilievskaia, O. A. Kniazevskaia, E. I. Sokolova, I. P. Starostina, Ia. N. Shchapov (M., 2002): 25. 
A clergyman should be smart and knowing in books, and sober-minded, and clever... if not so, he ought not go to that dignity even if he is a saint. And a rude and ignorant man should not be a clergyman, because ignorance is the worst $\sin .47$

In pseudo-John Chrysostom's Speech on false teachers, this thought was expressed in even clearer terms:

Understand what is said in the parable, that many shepherds hire workers to take care of their flock, and they themselves drink and sleep. In the same way do shepherds of speech-endowed sheep sleep in ignorance and rudeness and get drunk on unduly collected offerings, and they connive with the powers that be, and they do not want to teach correctly. ${ }^{48}$

This Speech was often characterized as a product of heretical literature. 49 "Because our teachers have grown rich with estates and have become blind... where do they take ignorance from if not from the absence of book reading."50 A collection of such articles in the second variant of Izmaragd and in Vlasfimiia (a component of the Trifonovskii collection) has often led researchers to think these texts were composed by heretics. The fact that all these texts only occur in Church literature together with the results of recent studies give us the possibility to disprove this supposition unambiguously. ${ }^{51}$ Growing demands to clergymen were parallel to the desire to raise their authority in the eyes of laymen. Metropolitan Photius angrily indicted the custom of oath taking by priests before laymen:

I have heard of this, how there is humiliation and disgrace of the dignity of the great God's priesthood here, and how they judge you: when somebody owes you

47. RNB, ms. Soph. 1262, f. 111 rev.: "Podobaet byti ereiu smyshlenu i khytru knigam, i trezvu, i umnu byti... ashche ne takomu, dobre by emu ne iti v toi chin, ashche i sviat. A grub nevezha nepodobna emu byti ereom, nevedenie ubo zlee est' sogreshenie."

48. Ibid., f. 109 rev. : "Razumeite zhe est' v prittsi, iako mnozi pastushi naimity naimuiut pastviti skota, a sami piiut, ili da spiat. Tako zhe i slovesnykh ovets pastushi spiat nevedeniem ili grubostiiu, no upivaiutsia nepravednym sobranym, potakovi deiushchim vlastelem i ne khotiat uchit' pravo."

49. The text was published twice: 1) A. I. Klibanov, in Issledovanie $i$ materialy po drevnerusskoi literature [Research and Materials on Ancient Russian Literature], (M., 1961): 300-312; 2) in Dukhovnaia kul'tura srednevekovoi Rusi [Spiritual Culture of Ancient Russia], (M., 1996): 301-305.

50. RNB, ms. Soph. 1262, f. 110 : "Uchiteli bo nasha napolnishasia bogatstvom imeniia i osleposha... otkudu bo vnide v ny nevedenie, iave li ot nepochitaniia knizhnogo."

51. See: B. M. Pudalov, "Sbornik 'Izmaragd' v drevnerusskoi pis'mennosti," Metodicheskie rekomendatsii po opisaniiu slaviano-russkikh rukopisnykh knig ["The Izmaragd Compendium in Ancient Russian Literature," Methodical Guide-Lines for Cataloguing Slavic-Russian Manuscript Books], vol. 3, part 2 (M., 1990). Sources of Vlasfimiia were canonic articles of Kormchie knigi, as well as numerous extracts from patrology texts and Commented Gospel. Detailed study of Vlasfimiia with the publication of this text is to be done by the author of this article in the near future. 
something, or when you are calumniated, they order you to take your priestly clothes on, and they judge you by such an oath. .2

The accusatory articles of the edifying anthologies of the fifteenth and sixteenth centuries were not products of the literature of heretics. These texts were full of telling criticism of the clergy, and the phenomenon of the strigol'niki heresy we should analyze as a fact of the same type. ${ }^{53}$ In that case it is more sensible to speak of change in religious conscience. In fifteenth-century Russia, the process of deep Christianization was rather active and a new type of religious conscience. The core of religious conscience of the tenth-thirteenth centuries included obligatory baptism, fasting, marriage; it was gradually completed with the awareness of the necessity of regular confession, observation of rules of repentance, regulations of funeral and commemorative rites. This process was characterized with the growth of the authority of priests, on the one hand, and with the raising of demands to them on the other - both were unknown in previous epochs. We are naturally far from describing a linear process: religious practice kept many traditional features of the old religious conscience, and the very process of shaping new piety took many decades during which phenomena of religious conscience of two epochs coexisted.

\section{6.}

We are far from interpreting ritual executions as forms of paganism. It is known that in the early medieval period the practice of ordeal (God's Judgement) was wide-spread. In such ordeals clergymen also participated, and ordeals could be used in the case of accusation in heresy. Contemporaries were sure that proven heretics should be given to "God's judgement" through the water test. ${ }^{54}$ In the twelfth century Bernard of Clairvaux questioned this practice. We have to stress the parallel between the mentioned facts in Western Europe and in Russia, where the tradition of ordeal was condemned by Serapion of Vladimir. ${ }^{55}$ An official prohibition for the clergy to take part in ordeals was made by the Lateran council of 1215 only. Since the thirteenth century all cases of accusation in witchcraft have been the subject of investigations held by the Inquisition.

52. AFED: 248 : "o tom slyshal esm', kako tuto unichizhenie i ponos na chin velikago bozhii svishchen'stva, i kako sudiat vas: gde vam chto vziati, ili kto pokleplet vas, i veliat vam obleshchi sebe vo vsiu odezhiu sviashchennicheskuiu, i takovoiu rotoiu sudiat vas."

53. See for instance a severe criticism of the vices of clergymen in the works of the accuser of Bogomils Cosmas the Priest (M. G. Popruzhenko, Kozma presviter, bolgarskii pisatel' $X$ veka [Cosmas the Priest, a Bulgarian Writer of the Tenth Century], (Sofia, 1936): 13-14).

54. A. Angenendt, Geschichte der Religiosität im Mittelalter, 2. Ausg. (Darmstadt, 2000): 195.

55. Biblioteka literatury drevnei Rusi, vol. 5 (SPb.): 380. For comparison, see: V. V. Mil’kov, Osmyslenie istorii v drevnei Rusi [Understanding the History of Ancient Rus], (SPb., 2000): 332. Comm. 10 . 
In the medieval Church different magic practices were regularly used, including fortune-telling on the Bible, wearing of sheets with Biblical texts on the neck or weather spelling with the Gospel of St. John, who was supposed to be "the son of thunder." 56 In the main variant of the Life of Novgorod Archbishop John (died 1185), there is the following episode: Novgorod citizens, suspecting their church ruler of the sin of fornication, led him "to the Velikii bridge which is on the river Volkhov" and "hanging him from the bridge, set him on a raft." 57 In 1228, Novgorod citizens turned out Archbishop Arsenius, whom they held responsible for an exceptionally rainy autumn:

They gathered an assembly in Iaroslav's yard, and went to the archbishop's court and said: the reason why the weather remains warm so late is that you ushered out Archbishop Anthony to Khutino, and took his see yourself after bribing the prince..$^{58}$

If a bishop suspected of behavior inappropriate for his rank and position could be blamed for natural disasters in Novgorod, one may ask whether the persons accused of the strigol'niki heresy could not be the victims of such accusations too. Even taking into account the strong points of the criticism of the official clergy by the heretics, the latter could not build up a stable counterbalance to the Church's organization that was deeply enrooted in the Novgorod Republic.

How could veneration of the Gospel, aspiration to follow Christ, making gifts to churches coexist with perceptions of the heretics as sorcerers in public opinion? We consider the answer on this question must be found in the area of religious consciences at a time of "cultural compromise," when non-Christian elements of beliefs and customs coexisted peacefully with the lowest level of church involvement in a specific religious practice.

\section{National Library of Russia \\ Saint Petersburg}

a.alexeev@nlr.ru

56. A. Angenendt, Geschichte der Religiosität..., op. cit.: 181.

57. “...nizvesivshe ego s mosta, posadisha na plot.” See: L. A. Dmitriev, Zhitiinye povesti russkogo Severa kak pamiatnik literatury XIII-XVII vV. [Vitæ from the Russian North as Monuments of 13th-17th Centuries Literature], (L., 1973): 153, 158. For a partial English translation of the Tale, see: S. Zenkovsky, Medieval Russia's Epics, Chronicles and Tales (New York, 1963), $2^{\text {nd }}$ ed. 1974: 261-264; for a complete German translation, see: E. Benz et alii, ed., Russische Heiligenlegenden (Zurich, 1953, Darmstadt, 1983): 459-469.

58. Novgorodskaia pervaia letopis' starshego i mladshego izvodov, p. 67, 272: "I stvorshe veche na Iaroslavli dvore, i poidosha na vladytsin dvor, rekuche: togo delai stoit teplo dlgo, vyprovodil Antoniia vladyku f Khutino, a sam sel, dav mzdu kniaziu." 